\title{
CAN HUMILITY EXIST WITHOUT POVERTY? A RESPONSE BY CAPPADOCIAN FATHERS AND JOHN CHRYSOSTOM
}

The Greek Fathers of the fourth century jointly recognized the virtue of humility as a starting point ( $\dot{\alpha} \rho \chi \dot{\eta}-$ the beginning, $\dot{\rho}^{\prime} \zeta \alpha-$ root, $\kappa \varepsilon \varphi \alpha \lambda \dot{\eta}-$ head) on the road of spiritual development and as the mother of all virtues $(\mu \eta \tau \eta \dot{\rho}$ $\alpha \rho \varepsilon \tau \hat{\omega} v)^{1}$. They emphasized, in the vein of spreading monastic movement, the close bond between humility and obedience, which was sought to be the closest to it among all the virtues ${ }^{2}$. In his work De iudicio Dei Saint Basil the Great equated the latter with the former demeanour. He levelled the virtue of lowliness - understood as the bereftment from all haughtiness opposing

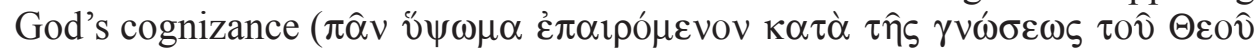
$\kappa \alpha \theta \alpha i \rho \varepsilon \hat{\imath} \tau \alpha \mathrm{l}$ ) - and equated it with obedience, defined as an inclusive surren-

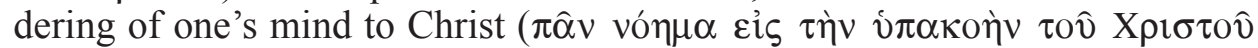
$\alpha i \chi \mu \alpha \lambda \omega \tau i \zeta \varepsilon \tau \alpha \imath)^{3}$. One may inquire whether the Cappadocian Fathers and John Chrysostom viewed the relationship between humility and poverty in an analogous manner?

Rev. prof. dr hab. Mariusz Szram - Department of Greek and Latin Patrology at the Institute of the History of the Church and Patrology at the Faculty of Theology of John Paul II Catholic University of Lublin, e-mail: m.szram@wp.pl.

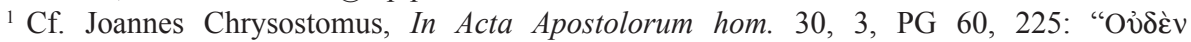

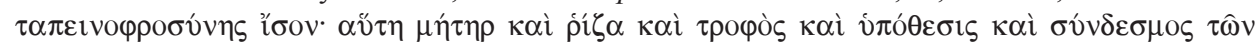

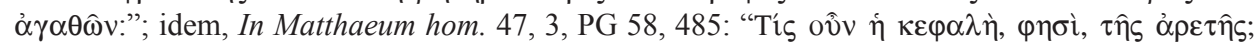

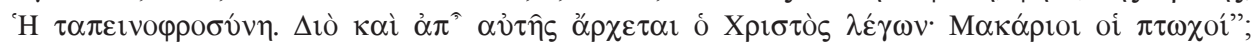

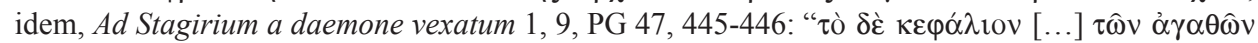

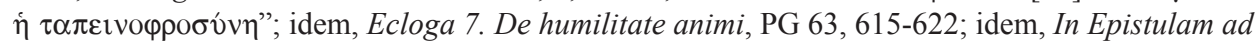
Romanos hom. 20, 3, PG 60, 599; idem, In epistulam ad Ephesios hom. 9, 2, PG 62, 71; J. Tremblay, St. John Chrysostom and the beatitudes, "Nicolaus. Rivista di teologia ecumenico-patristica. Nuova

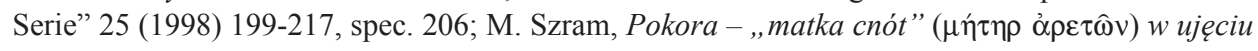
Bazylego Wielkiego i Jana Chryzostoma, RT 51 (2004) z. 4, 43-64.

${ }^{2}$ Cf. B. Degórski, Valori etici del monachesimo di San Girolamo. L'obbedienza / umiltà, in: L'etica cristiana nei secoli III e IV: Eredità e confronti. XXIV Incontro di studiosi dell'antichità cristiana, Roma 4-6 maggio 1995, SEA 53, Roma 1996, 317-337; M. Szram, Cnota pokory w nauczaniu greckich Ojców Kościoła IV wieku, Lublin 2014, 130-131.

${ }^{3}$ Basilius Caesariensis, De iudicio Dei 7, PG 31, 669B. 
It seems logical to treat these issues in a similar mode seeing as both attitudes are inextricably connected in the Bible ${ }^{4}$. In the Old Testament, the ones who humbly praised and requested God for assistance were known as the "poor" the "anawim" (Ps 22, 25; 34, 7; in Septuagint, and later on in the New Testament $-\pi \tau \omega \chi 0$ i). It should be noted that in the Septuagint, the term "anawim" was also explained by the term $\tau \alpha \pi \varepsilon \imath v o$, referring to any state of humility, particularly the one characterising the unassuming. The term "anawim" meant at first the social class of unfortunate and oppressed, deprived of the earthly goods and then, especially since the time of the prophet Zephaniah (cf. Zeph 2, 3; 3, 12) and in the wisdom literature (cf. Prov 18, 12; Sir 3, 18-19) began to take on a more religious character and denote the voluntary humility before the majesty of God and submission to His will ${ }^{5}$. The expected Messiah, as announced by Isaiah (cf. Is 11, 4), Micah (cf. Mic 5, 1) and Zechariah (Zech 9, 9-10) had to be humble yet poor. Humility in the Gospels - as in the Old Testament - was associated with poverty, understood both materially, physically and spiritually ${ }^{6}$. The poor, for whom Jesus was sent to preach the Good News, are referred to as the $\pi \tau \omega \chi$ oí $(\mathrm{Lu} \mathrm{4,} \mathrm{18;} \mathrm{Is} \mathrm{61,} \mathrm{1)} \mathrm{-} \mathrm{they} \mathrm{are} \mathrm{often} \mathrm{common} \mathrm{people} \mathrm{deprived}$ of worldly goods or health. Simultaneously, our Saviour addressed the poor

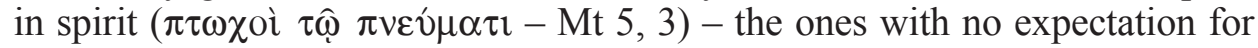
earthly splendour, nor boasting of their knowledge, admissive to teaching and education, that is to say humble towards the Divine Teacher, described by the

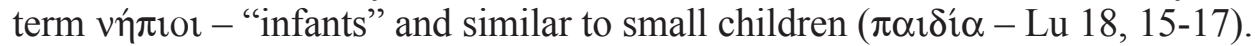
René-Antoine Gauthier stated that among the blessings voiced by Jesus at the mountain, two are predominantly correlated: to the poor in spirit $(\pi \tau \omega \chi 0 i \tau \widehat{\omega}$ $\pi v \varepsilon v ́ \mu \alpha \tau \imath$ ) and to the meek of heart ( $\pi \rho \alpha \varepsilon \hat{\imath} \varsigma$ - cf. Mt 5, 3. 5). The first are humble before God, other maintain a unassuming attitude toward brothers?

The Cappadocian Fathers and John Chrysostom while teaching on pride as the major flaw and encouraging the practice of humility, and unable to remain indifferent to the teaching of the Bible on the issue, considered as well the issue of relationship between humility and poverty. At present two issues as defined by Basil the Great, Gregory of Nyssa and John Chrysostom will be looked into: the distinction between material and spiritual poverty and the relationship the virtue of humility has with each one of them. Each of these authors' homilies have been analysed, in particular those commenting on the first of Christ's eight Beatitudes given on the mountain.

${ }^{4}$ Cf. Szram, Cnota pokory w nauczaniu greckich Ojców Kościoła IV wieku, s. 34-43.

${ }^{5}$ Cf. A. George, Pauvre, in: Dictionnaire de la Bible. Supplément 7, Paris 1962, 387-406; R.A. Gauthier, Magnanimité. L'idéal de la grandeur dans la philosophie païenne et dans la théologie chrétienne, Bibliothèque Thomiste 28, Paris 1951, 376-379.

${ }^{6}$ Cf. P. Adnès, Humilité, DSp VII 1146-1147; L. Gilen, Die Demut des Christen nach dem Neuen Testament, "Zeitschrift für Aszese und Mystik" 13 (1938) 266-284; Gauthier, Magnanimité, s. 396-399.

${ }^{7}$ Cf. Gauthier, Magnanimité, s. 401; Gilen, Die Demut des Christen, s. 266-284. 
Basil the Great, in his renowned homily on the virtue of humility, defined it as an act of crediting God alone with all the praise for good deeds and not exalting oneself above others, even if considering the greatest of sinners ${ }^{8}$. Used in the title of the homily term $\tau \alpha \pi \varepsilon 1 v o \varphi \rho o \sigma v ́ v \eta$ indicated always in the case of Basil, Cappadocian Fathers and John Chrysostom, a moral virtue while the term $\tau \alpha \pi \varepsilon i v o \sigma ı \varsigma$ had a broader significance and could mean the usual humility, modesty, poverty, not necessarily connected with man's interior, or even lowliness caused by sin or lower social status associated with poverty. The relationship between the terms $\tau \alpha \pi \varepsilon ı v o p \rho o \sigma v ́ v \eta$ and $\tau \alpha \pi \varepsilon i v o \sigma ı s$, and also between the concept of humility and poverty, is determined by Basil's formulation:

"the sufficient outward expression of humility [of spirit] is modesty (poverty)

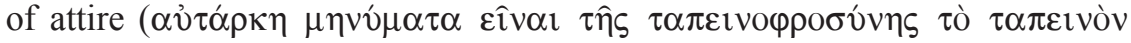
$\tau \circ \hat{\varepsilon} \varepsilon \dot{v} \delta \hat{u} \mu \alpha \tau \circ \varsigma)^{\prime \prime}$.

In Basil's belief the external visible material poverty is a sign of inner humility. Whereas, enrichment leads to exaltation - the constant desire and unhealthy competition - which promotes the development of the flaw of pride. It is no coincidence that Basil employed the same term $\tau$ v́pos, dating from the Stoic philosophy and meaning literally "smoke" and figuratively - "puffed", "flatulence", to both the rich and arrogant ${ }^{10}$.

Basil the Great displayed the close bond between richness and pride, plus humility and material poverty, but did not elaborate on the issue of these relationships. The one who analysed them in detail was Gregory of Nyssa, the author of the first known patristic set of homilies on the eight Beatitudes, written probably in the years 370-380 AD. Commenting on the first blessing of Jesus on Mount Tabor - "Blessed are the poor in spirit" (Mt 5, 3) - Nyssean characterises spiritual poverty distinguishing it noticeably from the usual material poverty. In his view, life in poverty in itself is not enough for a positive moral evaluation. It gains such great import only when the motive is spiritual (ó $\delta i \alpha$ iò $\pi v \varepsilon \hat{v} \mu \alpha \pi \tau \omega \chi \varepsilon v \omega v)$, namely the desire to attain real wealth of the soul, in which the striving for earthly wealth can only interfere ${ }^{11}$. In addition to the distinction between the material and spiritual poverty Gregory - in the vein of allegorical interpretations, which date back to Origen - introduced distinction between good and bad poverty $\left(\pi \varepsilon v^{\prime} \alpha\right)$. The first - considered by him to be joyful ( $\mu \alpha \kappa \alpha \rho i \zeta o \mu \varepsilon ́ v \eta)$ - signifies getting rid of vices and wicked-

${ }^{8}$ Cf. Basilius Caesariensis, De humilitate hom. 3-4, PG 31, 529C-533B; T. Špidlik, La sophiologie de S. Basile, Roma 1961, 73; Szram, Cnota pokory w nauczaniu greckich Ojców Kościoła IV wieku, s. 96-97.

${ }^{9}$ Basilius Caesariensis, Epistula 223, 3, PG 32, 325A, transl. by M.S.

${ }^{10}$ Cf. idem, Adversus Eunomium 1, 13, ed. B. Sesboüé - G.-M. de Durand - L. Doutreleau, vol.

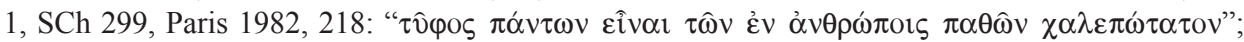
Diogenes Laertius, Vitae philosophorum VII 1, 117, ed. H.G. Huebnerus, vol. 2, Lipsiae 1831, 164.

${ }^{11}$ Cf. Gregorius Nyssenus, Orationes de beatudinibus 1, ed. J.F. Callahan, GNO 7/2, Leiden 1992,88 . 
ness, rejection of temptations of the devil and all evil; the second - worthy of dismissal ( $\alpha \pi$ ó $\beta \lambda \eta \tau o v)$ - a lack of spiritual goods in the form of basic virtues such as justice, wisdom, prudence. Both are independent of the state of the material possession, but - according to Gregory - one who has few worldly goods is evidently closer to good poverty, and vice versa: the evil of poverty pushes attachment to material goods beclouding what constitutes real wealth in human life ${ }^{12}$.

Spiritual poverty, coinciding largely with the good poverty for which Gregory calls, is in his belief tantamount to a voluntary humility, explicitly the virtue of humility ${ }^{13}$. A model for such understood spiritual poverty is for Gregory of Nyssa the Son of God, who became poor for people, humbly stripping Himself of His wealth of being through the adoption of human nature ${ }^{14}$. Humility - according to Gregory of Nyssa - is therefore on one hand a radical Christian recognition of the virtue of temperance (the ancient ideal of $\mu \varepsilon \sigma o ́ \tau \varepsilon \varsigma$ ), comprehended in theological terms. On the other hand, it is a special kind of poverty. It is a voluntary adoption of material deprivation due to a spiritual incentive and an attempt to be poor and humble like Christ in such a way as to maintain deference for another human being, regardless of his social position, since God Himself accepted along with the incarnation extreme humility and surrendering to decisions of the people. Humility as poverty - understood by Gregory in the vein of other Cappadocians - is a virtue most compatible with the nature of man as a being created, earthbound, and therefore unfit to preen and exalt himself above God the Creator, while recognizing God as his supreme good. Humility is a sign of the good poverty, set for acquisition of virtues, simultaneously excluding bad poverty, namely the lack of desire to obtain spiritual goods, independent of the state of material poverty.

From the first homily of Gregory of Nyssa on the eight Beatitudes one can conclude that for God's positive assessment deserves only such material poverty which is accompanied by spiritual poverty - that is recognition of the supremacy of the divine world instead of the earthly well-being - as well as the so-called good poverty: denunciation of vices and all wickedness, regardless of possession of material goods. Only the combination of material and spiritual poverty along with divesting oneself of the so-called evil paucity, or lack of spiritual goods in form the most important virtues - according to Gregory - becomes a prerequisite to converting into a humble man.

${ }^{12}$ Cf. ibidem, GNO 7/2, 82.

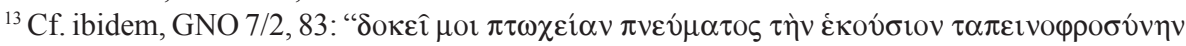

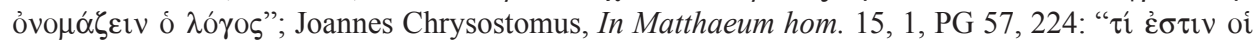

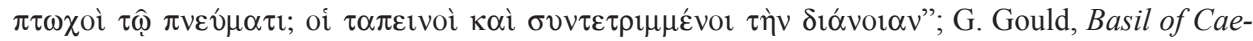
sarea and Gregory of Nyssa on the Beatitudes, StPatr 22 (1989) 15; Gauthier, Magnanimité, s. 400; Tremblay, St. John Chrysostom and the beatitudes, s. 208.

${ }^{14} \mathrm{Cf}$. Gregorius Nyssenus, Orationes de beatitudinibus 1, GNO 7/2, 88. 
Yet the question of existence of spiritual poverty without material poverty remains: is it plausible, and are both equally necessary to achieve the attitude of humility? Gregory of Nyssa does not provide a clear answer to this question, although he suggests that material poverty, or at least the lack of attachment to wealth, makes it easier to be humble. The fourth-century monastic approach, reflected in the teaching of Evagrius of Pontus, concerned with the desire of wealth ( $\varphi \imath \lambda \alpha \rho \gamma v \rho i \alpha)$ as the root of all evil ( $\dot{\rho}^{\prime} \zeta \alpha \alpha \pi \dot{\alpha} v \tau \omega \nu$ $\tau \hat{\omega} v \kappa \alpha \kappa \hat{\omega} v)^{15}$, lead one to the conclusion that without a material poverty humility is unfeasible. John Chrysostom in his homily on the first blessing, while discussing the spiritual poverty as closely associated with the attitude of humility, does not mention material poverty at all. However, in the homilies to the Letter to the Hebrews, he draws attention to the fact that in warding off arrogance and pride one finds especially helpful preserving material poverty ( $\pi \varepsilon v^{\prime} \alpha$ ), not attaching too much importance to worldly goods and using wealth to apt use ${ }^{16}$. The preacher's idea evolves in the direction that material poverty facilitates the attitude of humility, but is not strictly necessary to achieve it, as opposed to spiritual poverty, which in this situation is a conditio sine qua non. Seemingly we are dealing with a continuation of the approach known from the work of Clement of Alexandria, namely Quis dives salvetur? ${ }^{17}$ One can posses wealth, yet should make good use of it for other in need, and not get attached to it too much. Regardless of the affluence one should strive to approach spiritual poverty, that is the humble recognition that all spiritual and material good is derived from God. It can therefore be concluded that in the conviction of Gregory of Nyssa and John Chrysostom people that are the poor in spirit, to whom refers the first blessing, are synonymous with the humble folk. Material poverty facilitates acquisition of the virtue of humility and aids in its keeping, yet only if driven by a spiritual incentive.

\section{CZY POKORA MOŻE ISTNIEĆ BEZ UBÓSTWA? STANOWISKO OJCÓW KAPADOCKICH I JANA CHRYZOSTOMA}

\section{(Streszczenie)}

Greccy Ojcowie Kościoła IV w. uznawali zgodnie cnotę pokory za punkt wyjścia na drodze duchowego doskonalenia oraz za matkę wszystkich cnót. W duchu rozwijającego się monastycyzmu podkreślali przede wszystkim ścisły związek pokory z posłuszeństwem jako cnotą najbardziej jej pokrewną. Autor

${ }^{15}$ Cf. Evagrius Ponticus, De malignis cogitationibus 1, ed. P. Géhin - C. Guillaumont - A. Guillaumont, SCh 438, Paris 1998, 150; L. Misiarczyk, Osiem , logismoi” w pismach Ewagriusza z Pontu, Kraków 2007, 242-243.

${ }^{16}$ Cf. Joannes Chrysostomus, In epistulam ad Hebraeos hom. 2, 5, PG 63, 26-28.

${ }^{17}$ Cf. Clemens Alexandrinus, Quis dives salvetur, ed. L Fruchtel, GCS 17 (Klemens Werke 3), Berlin 1970, 159-191; J. Pałucki, Dobre bogactwo, Lublin 1992. 
artykułu stara się znaleźć odpowiedź na pytanie, w jaki sposób postrzegali oni relację między pokorą i ubóstwem, mającą głęboką tradycję biblijną. Już w Starym Testamencie ludzie ubodzy ( $\pi \tau$ ఒớ) jako znajdujący się w potrzebie byli uważani za szczególnie skromnych i otwartych na pokorne szukanie pomocy u Boga i drugiego człowieka. Ojcowie Kapadoccy i Jan Chryzostom definiowali cnotę pokory jako przypisywanie wszelkiej chwały za dokonane dobre czyny samemu Bogu i niewywyższanie się ponad innych ludzi, nawet największych grzeszników. Zagadnienie związku ubóstwa z tak rozumianą pokorą poruszali komentując przede wszystkim pierwsze $\mathrm{z}$ ośmiu błogosławieństw Chrystusa na górze. $\mathrm{Z}$ analiz homilii poświęconych tej kwestii przez Grzegorza z Nyssy i Jana Chryzostoma wynikają następujące wnioski:

1) istnieją dwa rodzaje ubóstwa: duchowe i materialne, które są od siebie zależne;

2) istnieje także tzw. „złe ubóstwo”, które oznacza brak podstawowych cnót; jest ono przeszkodą do osiągnięcia cnoty pokory;

3) ubóstwo materialne ułatwia postawę pokory, ale nie wystarcza do osiągnięcia tej cnoty;

4) cnota pokory jest natomiast niemożliwa bez ubóstwa duchowego, które otwiera na Boga;

5) ludzie ubodzy w duchu, których dotyczy pierwsze błogosławieństwo, są synonimem ludzi pokornych.

Key words: Cappadocians Fathers, John Chrysostom, virtue of humility, virtue of poverty, theology of IV ${ }^{\text {th }}$ century.

Słowa kluczowe: Ojcowie Kapadoccy, Jan Chryzostom, cnota pokory, cnota ubóstwa, teologia IV wieku. 